\title{
Penerapan Metode Naive Bayes dalam Memprediksi Kepuasan Mahasiswa Terhadap Cara Pengajaran Dosen
}

\author{
Desi Ratna Sari¹, Dedy Hartama², Irfan Sudahri Damanik ${ }^{3}$, Anjar Wanto ${ }^{4}$ \\ STIKOM Tunas Bangsa Pematangsiantar \\ Jl. Jendral Sudirman Bl ok A No. 1,2,3 Pematangsiantar \\ desiratnasari054@gmail.com
}

\begin{abstract}
This research aims to classify in determining student satisfaction with teaching methods at STIKOM Tunas Bangsa. Data obtained from the results of the 2015 and 2016 semester student questionnaires were odd, with a sample of 80 students. Attributes used are 4, namely communication (C1), Building learning atmosphere (C2), Assessment of students (C3) and delivery of material (C4). The method used in this study is the Naïve Bayes Algorithm and is processed using RapidMiner studio 5.3 software to determine student satisfaction with teaching methods. Training data used 100 data while testing data used in manual calculations as much as 5 data. From the results of data testing the five data expressed satisfaction with the way teaching lecturers at STIKOM Tunas Bangsa. While the training data that is processed with RapidMiner has an accuracy of 92.00\%. With this analysis, it is expected to be able to help higher education institutions to evaluate the performance of lecturers, especially in evaluating one of the three triharma colleges, namely the teaching method of lecturers.
\end{abstract}

Keywords: Students, Teaching Lecturer, Data Mining, Naïve Bayes

Abstrak- Penelitian ini bertujuan untuk melakukan klasifikasi dalam menentukan kepuasan mahasiswa terhadap cara pengajaran dosen di STIKOM Tunas Bangsa. Data didapat dari hasil kuesioner mahasiswa angkatan 2015 dan 2016 semester ganjil, dengan sampel data 80 mahasiswa. Atribut yang digunakan sebanyak 4, yaitu komunikasi (C1), Membangun suasana belajar (C2), Penilaian terhadap mahasiswa (C3) dan penyampaian terhadap materi (C4). Metode yang digunakan dalam penelitian ini adalah Algoritma Naïve Bayes dan diproses menggunakan software RapidMiner studio 5.3 untuk menentukan kepuasan mahasiswa terhadap cara pengajaran dosen. Data training yang digunakan 100 data sedangkan data testing yang digunakan dalam perhitungan manual sebanyak 5 data. Dari hasil data testing kelima data menyatakan puas terhadap cara pengajaran dosen di STIKOM Tunas Bangsa. Sedangkan data training yang di proses dengan RapidMiner memiliki akurasi sebesar $92.00 \%$. Dengan analisis ini diharapkan dapat membantu pihak perguruan tinggi untuk mengevaluasi kinerja dosen khususnya dalam mengevaluasi salah satu tri darma perguruan tinggi yaitu cara pengajaran dosen.

Kata kunci : Mahasiswa, Pengajaran Dosen, Data Mining, Nä̈ve Bayes

\section{PENDAHULUAN}

STIKOM Tunas Bangsa merupakan salah satu perguruan tinggi swasta yang memiliki peranan untuk memberikan kepuasan kepada setiap mahasiswa. Kepuasan Mahasiswa tersebut dapat berupa kepuasan terhadap cara pengajaran dosen. Kepuasan mahasiswa terhadap cara pengajaran dosen merupakan salah satu faktor yang sangat mempengaruhi dalam menentukan keberhasilan suatu 
Perguruan Tinggi. Tidak hanya mahasiswa yang memiliki kewajiban untuk memiliki kemampuan dan keahlian, dosen juga dituntut untuk pandai dalam proses penyampaian materi sehingga dapat dengan mudah dipahami dan mahasiswa menjadi puas. Dalam menyampaikan materi setiap dosen memiliki cara pengajaran yang berbeda-beda satu sama lainnya kepada mahasiswa mereka untuk dapat dipahami oleh mahasiswanya. Perbedaan cara pengajaran tersebut berpengaruh pada hasil yang diperoleh oleh mahasiswa yaitu puas dan tidak puasnya mahasiswa. Proses belajar mengajar merupakan suatu proses yang dijalankan oleh seorang dosen atas dasar hubungan timbal balik yang berlangsung dalam situasi menyampaikan sebuah pengetahuan terhadap mahasiswa untuk mencapai suatu tujuan tertentu[1]. Dalam menjalankan proses belajar mengajar seorang dosen harus memperhatikan cara mereka dalam menyampaikan suatu materi. Seorang dosen diharapkan memiliki sikap capability dan loyality, yakni dalam bidang ilmu yang diajarkannya seorang dosen harus memiliki kemampuan dalam mengajar yang baik agar dapat dengan mudah dipahami oleh mahasiswanya.

Data Mining merupakan proses maupun kegiatan mengumpulkan sekumpulan data yang memiliki kapasistas yang besar untuk di ekstraksi sehingga menjadi informasi yang dapat digunakan [2]-[7]. Dalam hal ini peneliti menggunakan metode Naive Bayes. Metode Naive Bayes digunakan dalam penelitian ini karena metode ini merupakan teknik prediksi yang mencari probabilitas sederhana berdasarkan pada Teorema Bayes dengan asumsi independensi yang kuat. Adapun Jurnal yang menjadi acuan dalam menyelesaian metode Nä̈ve Bayes yaitu penelitian yang membahas tentang proses pengklasifikasian kelayakan keluarga penerima beras rastra dengan atribut yang digunakan adalah jumlah tanggungan, kepala rumah tangga, kondisi rumah, jumlah penghasilan, dan status pemilik rumah[8]. Penelitian selanjutnya yang menjadi referensi yaitu penelitian yang membahas tentang mengklasifikasi kemungkinan mahasiswa menderita obesitas dengan atribut yang digunakan antara lain, lingkar perut, berat badan dan tinggi badan[9]. Dan adapun jurnal lain yang berkaitan dengan penelitian ini yaitu penelitian dalam menganalisis kepuasan mahasiswa terhadap kinerja dosen. Indikator yang digunakan dalam penelitian tersebut sebanyak 4 yaitu Kompetensi Pedagogik, Kompetensi Profesional, Kompetensi Kepribadian dan Kompetensi Sosial [10]. Tujuan dari penelitian ini adalah membantu pihak perguruan tinggi khususnya pihak pendidikan STIKOM Tunas Bangsa dalam mengevaluasi kinerja dosen dalam proses belajar mengajar sehingga dapat dilakukan antisipasi dalam memperbaikan dan meningkatkan kinerja dosen khususnya cara pengajaran dosen di masa yang akan datang serta menentukan apakah dosen telah berhasil dalam menjalankan salah satu Tri Darma Perguruan Tinggi yaitu pengajaran. 


\section{METODOLOGI PENELITIAN}

\subsection{Metode Pengumpulan Data}

Metode pengumpulan data yang dilakukan yaitu :

a. Penelitian Kepustakaan (Libarry Research) - memanfaatkan perpustakaan, buku, prosiding atau jurnal sebagai media untuk bahan referensi dalam menentukan faktor, parameter dan label yang digunakan untuk penelitian.

b. Kuesioner - proses pengumpulan data atau informasi dengan cara memberikan sebuah pertanyaan atau pernyatan kepada orang lain. Penulis memberikan kuesioner kepada mahasiswa STIKOM Tunas Bangsa Pematangsiantar angkatan 2016 dan angkatan 2017.

c. Wawancara - Penulis meelakukan wawancara dengan memberikan pertanyaan kepada Lembaga Penjamin Mutu (LPM) di STIKOM Tunas Bangsa Pematangsiantar.

d. Pengamatan Langsung (Observasi) - Penulis melakukan pengamatan langsung terhadap mahasiswa dengan cara mengamati proses belajar mengajar yang dilakukan di STIKOM Tunas Bangsa Pematangsiantar.

\subsection{Data Mining}

Proses penggalian dan pertambangan pengetahuan dari sejumlah data yang besar, database atau repository database lainnya.tujuan utama dari penambangan data ini untuk menemukan pengetahuan baru yang tersembunyi dari database tersebut[11].

\subsection{Klasifikasi}

Klasifikasi merupakan proses untuk menemukan fungsi dan model yang dapat membedakan atau menjelaskan konsep atau kelas data dengan tujuan memperkirakan kelas yang tidak diketahui dari suatu objek[12] . Klasifikasi juga dapat diartikan sebagai suatu pekerjaan menentukan objek data yang selanjutnya dimasukan kedalam kelas tertentu berdasarkan sejumlah kelas yang ada. Dua pekerjaan utama yang dilakukan dalam klasifikasi yaitu membangun sebuah model sederhana, melakukan pengenalan /klasifikasi/ prediksi pada suatu objek data lain agar dapat diketahui pada kelas mana objek data tersebut disimpan [13].

\subsection{Naive Bayes}

Naïve Bayes merupakan metode pengklasifikasian probabilitas dan statistik yang dikemukakan oleh ilmuan inggris Thomas Bayes, yaitu memprediksi kemungkinan yang terjadi di masa depan berdasarkan kejadian di masa sebelumnya[14].

Untuk menyelesaikan metode Naïve Bayes dapat dilakukan dengan persamaan-persamaan sebagai berikut:

$P(H \mid X)=\frac{P(X \mid H) * P(H)}{P(X)}$

Keterangan :

$\mathrm{X} \quad$ : Data dengan class yang belum diketahui

$\mathrm{H} \quad$ : Hipotesis data merupakan suatu class spesifik 
$\mathrm{P}(\mathrm{H} \mid \mathrm{X})$ : Probabilitas hipotesis $\mathrm{H}$ berdasarkan kondisi $\mathrm{X}$ (posteriori probabilitas) $\mathrm{P}(\mathrm{H})$ : Probabilitas hipotesis $\mathrm{H}$ (prior probabilitas)

$\mathrm{P}(\mathrm{X} \mid \mathrm{H})$ : Probabilitas $\mathrm{X}$ berdasarkan kondisi pada hipotesis $\mathrm{H}$

$\mathrm{P}(\mathrm{X}) \quad$ : Probabilitas $\mathrm{X}$

Penjabaran lebih lanjut rumus Naïve Bayes tersebut dilakukan dengan menjabarkan secara terperinci $\left(\mathrm{C} \mid \mathrm{X}_{1} \ldots, \mathrm{X}_{\mathrm{n}}\right)$ menggunakan aturan perkalian sebagai berikut.

$$
\begin{aligned}
\mathrm{P}\left(\mathrm{C} \mid \mathrm{x}_{1}, \ldots \ldots, \mathrm{X}_{\mathrm{n}}=\right. & \mathrm{P}(\mathrm{C}) \mathrm{P}\left(\mathrm{x}_{1}, \ldots . ., \mathrm{x}_{\mathrm{n}} \mid \mathrm{C}\right) \\
= & \mathrm{P}(\mathrm{C}) \mathrm{P}\left(\mathrm{X}_{1} \mid \mathrm{C}\right) \mathrm{P}\left(\mathrm{X}_{2}, \ldots, \mathrm{X}_{\mathrm{n}} \mid \mathrm{C}, \mathrm{X}_{1}\right) \\
= & (\mathrm{C}) \mathrm{P}\left(\mathrm{X}_{1} \mid \mathrm{C}\right) \mathrm{P}\left(\mathrm{X}_{2} \mid \mathrm{C}, \mathrm{X}_{1}\right) \mathrm{P}\left(\mathrm{X}_{3}, \ldots \mathrm{X}_{\mathrm{n}} \mid \mathrm{C}, \mathrm{X}_{1}, \mathrm{X}_{2}(\mathrm{C}) \mathrm{P}\left(\mathrm{X}_{1} \mid \mathrm{C}\right)\right. \\
& \mathrm{P}\left(\mathrm{X}_{2} \mid \mathrm{C}, \mathrm{X}_{1}\right) \mathrm{P}\left(\mathrm{X}_{3} \mid \mathrm{C}, \mathrm{X}_{1}, \mathrm{X}_{2}\right) \mathrm{P}\left(\mathrm{X}_{4}, \ldots, \mathrm{X}_{\mathrm{n}} \mid \mathrm{C}, \mathrm{X}_{1}, \mathrm{X}_{2}, \mathrm{X}_{3}\right) \mathrm{P}(\mathrm{C}) \\
= & \mathrm{P}\left(\mathrm{X}_{1} \mid \mathrm{C}\right) \mathrm{P}\left(\mathrm{X}_{2} \mid \mathrm{C}, \mathrm{X}_{1}\right) \mathrm{P}\left(\mathrm{X}_{3} \mid \mathrm{C}, \mathrm{X}_{1}, \mathrm{X}_{2}\right) \ldots \\
& \mathrm{P}\left(\mathrm{X}_{\mathrm{n}} \mid \mathrm{C}, \mathrm{X}_{1}, \mathrm{X}_{2}, \mathrm{X}_{3}, \ldots . . \mathrm{X}_{\mathrm{n}-1 \ldots . .}\right.
\end{aligned}
$$

Jika semakin banyak faktor-faktor yang semakin kompleks yang berpengaruh terhadap nilai probabilitas, maka semakin tidak mungkin untuk menghitung nilai tersebut satu persatu. Proses perhitungan akan semakin susah untuk dilakukan, maka disinilah digunakan asumsi independensi yang sangat tinggi, bahwa masingmasing atribut dapat saling bebas. Dengan asumsi tersebut, diperlukan persamaan 3 :

$P\left(X_{i} \mid X_{j}\right)=\frac{P\left(X_{i}\right) P\left(X_{j}\right)}{P\left(X_{j}\right)}=\frac{P\left(X_{i} \cap X_{j}\right)}{P\left(X_{j}\right)}=P\left(X_{i}\right)$

Untuk $\mathrm{i} \neq \mathrm{j}$, sehingga

$P\left(X_{i} \mid C, X_{j}=P\left(X_{i} \mid C\right)\right.$

Dari persamaan 2.3 tersebut dapat di ambil kesimpulan bahwa asumsi independensi membuat syarat perhitungan menjadi lebih sederhana. Selanjutnya penjabaran $(P(C / X 1, \ldots . ., X n)$ dapat disederhanakan menjadi persamaan 4 :

$$
P\left(X_{2} \mid C\right) P\left(X_{3} \mid C\right) \ldots P\left(C \mid X_{1}, \ldots X_{n}\right)=P\left(X_{1} \mid C\right)=\prod_{i=1}^{n} p(X i \mid C)
$$

Keterangan :

$\prod_{i=1}^{n} P\left(X_{i} \| C\right)=$ perkalian ranting antar atribut.

Persamaan 4 merupakan teorema bayes yang kemudian akan digunakan untuk melakukan perhitungan klasifikasi. Untuk klasifikasi dengan data continue atau data angka menggunakan rumus distribusi Gaussian dengan 2 parameter : mean $\mu$ dan varian $\sigma$ :

$$
P\left(X_{i}=X_{i} \mid C=c_{j}\right)=\frac{1}{\sqrt{2 \pi \sigma i j}} \exp \frac{(x i-\mu i j) 2}{2 \sigma 2 i j}
$$


Keterangan :

$\mathrm{P}$ : Peluang

$\mathrm{X}_{\mathrm{i}}$ : Atribut ke i

$\mathrm{X}_{\mathrm{j}}$ : Nilai atribut ke i

C : Kelas yang dicari

$\mathrm{C}_{\mathrm{i}}$ : Sub kelas Y yang dicari

$\mu$ : Menyatakan rata-rata dari seluruh atribut

$\sigma$ : Deviasi standar, menyatakan varian dari seluruh atribut.

Dalam metode Naïve Bayes diperlukan data latih dan data uji yang ingin diklasifikasikan. Semakin banyak data latih yang yang dilibatkan, semakin baik hasil yang prediksi yang diberikan. Menghitung $\mathrm{P}\left(\mathrm{C}_{\mathrm{i}}\right)$ yang merupakan probabilitas prior untuk setiap sub kelas $C$ yang akan dihasilkan menggunakan persamaan 6 :

$$
P(C i)=\frac{S i}{s}
$$

Si adalah jumlah data training dari kategori $\mathrm{Ci}$, dan s adalah jumlah total data training. Menghitung $\mathrm{P}\left(\mathrm{X}_{\mathrm{i}} \mid \mathrm{C}_{\mathrm{i}}\right)$ yang merupakan probabilitas posterior Xi dengan syarat $\mathrm{C}$ menggunakan persamaan 4 .

\section{HASIL DAN PEMBAHASAN}

\subsection{Penentuan Kriteria dan Alternatif}

Bagian ini menerangkan bagaimana tahapan dan proses Naive bayes dalam menentukan kepuasan mahasiswa terhadap cara pengajaran dosen. Penelitian ini menggunakan 4 kriteria penilaian, yaitu: Komunikasi (C1), Membangun Suasana belajar(C2), Penilaian Terhadap Mahasiswa (C3), Penyampaian Terhadap Materi (C4). Alternatif yang digunakan pada penelitian adalah nama- nama mahasiswa yang menjawab pertanyaan dari kuesioner.

\subsection{Perhitungan Manual}

Tabel 1. Data penelitian

\begin{tabular}{|c|c|c|c|c|c|}
\hline $\begin{array}{c}\text { Respo } \\
\text { nden }\end{array}$ & $\begin{array}{c}\text { Komunik } \\
\text { asi }\end{array}$ & $\begin{array}{c}\text { Membangun } \\
\text { Suasana } \\
\text { Belajar }\end{array}$ & $\begin{array}{c}\text { Penilaian } \\
\text { Terhadap } \\
\text { Mahasiswa }\end{array}$ & $\begin{array}{c}\text { Penyampai } \\
\text { an } \\
\text { Terhadap } \\
\text { Materi }\end{array}$ & Klasifikasi \\
\hline R1 & C & C & C & B & Tidak Puas \\
\hline R2 & C & C & K & K & Tidak Puas \\
\hline R3 & SB & SB & B & C & Puas \\
\hline R4 & B & C & C & C & Puas \\
\hline R5 & B & B & B & B & Puas \\
\hline R6 & B & B & B & B & Puas \\
\hline R7 & C & B & B & SB & Puas \\
\hline R8 & B & C & C & SB & Tidak Puas \\
\hline R9 & SB & B & B & B & Puas \\
\hline R10 & C & B & $:$ & B & $:$ \\
\hline$:$ & $:$ & $:$ & SB & B & Puas \\
\hline R98 & SB & SB & SB & \\
\hline R99 & B & B & &
\end{tabular}




\begin{tabular}{|c|c|c|c|c|c|}
\hline Respo & Komunik & Membangun & Penilaian & Penyampai & Klasifikasi \\
\hline R100 & SB & SB & B & B & Puas \\
\hline R101 & B & B & SB & B & $?$ \\
\hline R102 & B & B & B & B & $?$ \\
\hline R103 & B & SB & B & B & $?$ \\
\hline R104 & B & SB & C & B & $?$ \\
\hline R105 & C & B & SB & B & $?$ \\
\hline
\end{tabular}

Setelah data telah ditentukan, langkah selanjutnya penulis menghitung jumlah puas dan tidak puas berdasarkan tabel 3.2. Dari 100 data latih yang digunakan, diketahui kelas puas sebanyak 78 data, dan kelas tidak puas sebanyak 22 data. Perhitungan probabilitas prior kemungkinan puas dalam menentukan kepuasan mahasiswa terhadap cara pengajaran dosen dapat dilihat pada persamaan (6), yaitu :

$P($ Puas $)=\frac{78}{100}=0,780$

Sedangkan perhitungan probabilitas tidak puas yaitu :

$P($ Tidak Puas $)=\frac{22}{100}=0,220$

Setelah probabilitas dari masing-masing prior telah diketahui, selanjutnya penulis menghitung masing-masing probabilitas dari setiap kriteria yang digunakan. Kriteria yang digunakan penulis yaitu komunikasi, membangun suasana belajar, penilaian terhadap mahasiswa dan penyampaian terhadap materi. Dalam menentukan probabilitas setiap kriteria, penulis menghitung bagian-bagian yang terdapat pada setiap kriteria, pada penelitian ini bagian-bagian yang terdapat dalam setiap kriteria menggunakan skala linkert 5 yaitu SB,B,C,K dan SK. Sehingga dalam menentukan probabilitas setiap kriteria dilakukan dengan menghitung jumlah puas dan tidak puas pada skala linkert yang digunakan. Sehingga perhitungan probabilitas masing-masing kriteria dapat dilihat pada beberapa tabel-tabel berikut. Untuk menghitung probabilitas kemungkinan dari kriteria komunikasi dapat dilihat pada tabel 2 sebagai berikut.

Tabel 2. Probabilitas Kriteria Komunikasi

\begin{tabular}{|c|c|c|c|c|}
\hline \multirow{2}{*}{ Komunikasi } & \multicolumn{2}{|c|}{ Jumlah Ke jadian Dipilih } & \multicolumn{2}{c|}{ Probabilitas } \\
\cline { 2 - 5 } & Puas & Tidak Puas & Puas & Tidak Puas \\
\hline SB & 16 & 0 & 0,2051 & O \\
\hline B & 47 & 8 & 0,6026 & 0,3636 \\
\hline C & 15 & 13 & 0,1923 & 0,5909 \\
\hline K & O & 1 & 0 & 0,0455 \\
\hline SK & O & 0 & 0 & 0 \\
\hline Jumlah & $\mathbf{7 8}$ & $\mathbf{2 2}$ & $\mathbf{1}$ & 1 \\
\hline
\end{tabular}

Untuk menghitung probabilitas kemungkinan dari kriteria membangun suasana belajar dapat dilihat pada tabel 3. 
Tabel 3. Probabilitas Membangun Suasana Belajar

\begin{tabular}{|c|c|c|c|c|}
\hline $\begin{array}{c}\text { Membangun } \\
\text { Suasana Belajar }\end{array}$ & \multicolumn{2}{|c|}{ Jumlah Kejadian Dipilih } & \multicolumn{2}{c|}{ Probabilitas } \\
\cline { 2 - 5 } & Puas & Tidak Puas & Puas & Tidak Puas \\
\hline SB & 21 & 1 & 0,2692 & 0,0455 \\
\hline B & 52 & 5 & 0,6667 & 0,2273 \\
\hline C & 5 & 14 & 0,0641 & 0,6364 \\
\hline K & 0 & 2 & 0 & 0,0909 \\
\hline SK & 0 & 0 & 0 & 0 \\
\hline Jumlah & $\mathbf{7 8}$ & $\mathbf{2 2}$ & $\mathbf{1}$ & $\mathbf{1}$ \\
\hline
\end{tabular}

Untuk menghitung probabilitas kemungkinan dari kriteria penilaian terhadap mahasiswa dapat dilihat pada tabel 4 .

Tabel 4. Probabilitas Penilaian Terhadap Mahasiswa

\begin{tabular}{|c|c|c|c|c|}
\hline Penilaian Terhadap Mahasiswa & \multicolumn{2}{|c|}{ Jumlah Kejadian Dipilih } & \multicolumn{2}{c|}{ Probabilitas } \\
\cline { 2 - 5 } & Puas & Tidak Puas & Puas & Tidak Puas \\
\hline SB & 18 & 1 & 0,2308 & 0,0455 \\
\hline B & 50 & 4 & 0,6410 & 0,1818 \\
\hline C & 10 & 14 & 0,1282 & 0,6364 \\
\hline K & 0 & 3 & 0 & 0,1364 \\
\hline SK & 0 & 0 & 0 & 0 \\
\hline Jumlah & $\mathbf{7 8}$ & $\mathbf{2 2}$ & $\mathbf{1}$ & $\mathbf{1}$ \\
\hline
\end{tabular}

Untuk menghitung probabilitas kemungkinan dari kriteria penyampaian materi dapat dilihat pada tabel 5.

Tabel 5. Probabilitas Penyampaian Terhadap Materi

\begin{tabular}{|c|c|c|c|c|}
\hline $\begin{array}{c}\text { Penyampaian } \\
\text { Terhadap Materi }\end{array}$ & \multicolumn{2}{|c|}{ Jumlah Kejadian Dipilih } & \multicolumn{2}{c|}{ Probabilitas } \\
\cline { 2 - 5 } & Puas & Tidak Puas & Puas & Tidak Puas \\
\hline SB & 19 & 0 & 0,2436 & 0 \\
\hline B & 53 & 6 & 0,6795 & 0,2727 \\
\hline C & 6 & 10 & 0,0769 & 0,4545 \\
\hline K & 0 & 6 & 0 & 0,2727 \\
\hline SK & 0 & 0 & 0 & 0 \\
\hline Jumlah & $\mathbf{7 8}$ & $\mathbf{2 2}$ & $\mathbf{1}$ & $\mathbf{1}$ \\
\hline
\end{tabular}

Setelah masing-masing probabilitas kriteria telah diketahui, langkah selanjutnya adalah menghitung nilai dari salah satu nilai yang diberikan responden untuk menentukan nilai klasifikasi. Berdasarkan data training pada tabel 1 pada data responden 101 sampai dengan 105 dilakukan klasifikasi ke dalam kelas puas. Rumus yang digunakan dalam menentukan kelas puas dapat dilihat pada persamaan (4). Sehingga untuk menghitung nilai puas pada data responden 101 sampai dengan 105 adalah sebagai berikut.

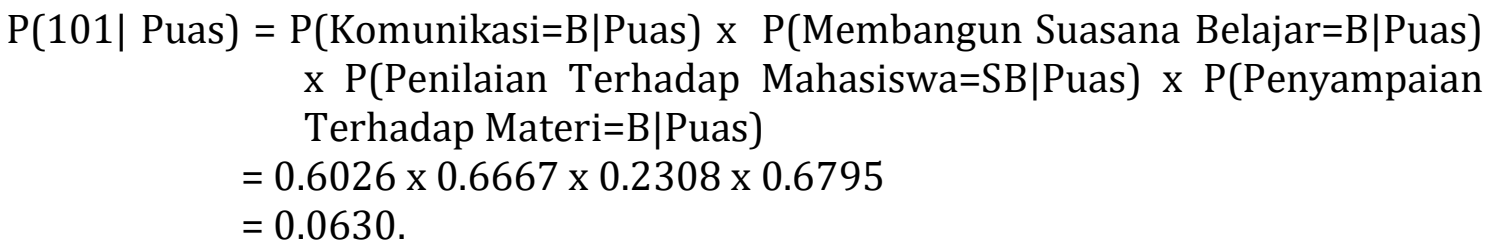


$\mathrm{P}(102 \mid$ Puas $)=\mathrm{P}($ Komunikasi $=\mathrm{B} \mid \mathrm{Puas}) \times \mathrm{P}($ Membangun Suasana

Belajar=B|Puas) $\times$ P(Penilaian Terhadap

Mahasiswa $=\mathrm{B} \mid$ Puas $) \times \mathrm{P}($ Penyampaian Terhadap

Materi $=\mathrm{B} \mid$ Puas $)=0.6026 \times 0.6667 \times 0.6410 \times 0.6795$ $=0,1750$.

Dan begitu seterusnya sampai dengan P(105|Puas).

Sedangkan untuk menghitung nilai tidak puas pada data ke-101 sampai dengan 105 rumus yang digunakan sama dengan rumus untuk menentukan nilai puas. Sehingga untuk mendapatkan nilai dilakukan sebagai berikut :

$\mathrm{P}(101 \mid$ Tidak Puas $)=\mathrm{P}($ Komunikasi $=\mathrm{B} \mid$ Tidak Puas $) \mathrm{x} \quad \mathrm{P}($ Membangun Suasana Belajar=B|Tidak Puas) x P(Penilaian Terhadap

Mahasiswa=SB|Tidak Puas) x P(Penyampaian

Terhadap Materi $=\mathrm{B} \mid$ Tidak Puas) $=0.3636 \mathrm{x}$

$0.2273 \times 0.0455 \times 0.2727=0,0010$

$\mathrm{P}(102 \mid$ Tidak Puas $)=\mathrm{P}($ Komunikasi $=\mathrm{B} \mid$ Tidak Puas $) \mathrm{x} \quad \mathrm{P}($ Membangun Suasana Belajar=B|Tidak Puas) $\times$ P(Penilaian Terhadap

Mahasiswa=B|Tidak Puas) $\times$ P(Penyampaian

Terhadap Materi $=\mathrm{B} \mid$ Tidak Puas) $=0.3636 \mathrm{x}$

$0.2273 \times 0.1818 \times 0.2727=0,0041$.

Dan begitu seterusnya sampai dengan P(105|Tidak Puas).

Setelah nilai puas dan tidak puas pada data 101 sampai dengan 105 telah diketahui. Selanjutnya penulis melakukan perhitungan maksimal masing-masing klasifikasi. Perhitungan data responden 101 sampai dengan 105 untuk menghitung pemaksimalan nilai puas yaitu

$\mathrm{P}(\mathrm{Puas} \mid \mathrm{C})=\mathrm{P}(\mathrm{Rn} \mid \mathrm{C}) * \mathrm{P}($ Puas $)$

$=\mathrm{P}(101 \mid \mathrm{C}) * \mathrm{P}(\mathrm{Puas})$

$=0.0630 \times 0.780=0.0491$.

$\mathrm{P}($ Puas $\mid \mathrm{C})=\mathrm{P}(\mathrm{Rn} \mid \mathrm{C}) * \mathrm{P}($ Puas $)$

$=\mathrm{P}(102 \mid \mathrm{C}) * \mathrm{P}($ Puas $)$

$=0.1750 \times 0.780=0.1365$.

Dan begitu seterusnya sampai dengan data ke 105.

Sedangkan perhitungan maksimal nilai tidak puas pada data responden 101 sampai dengan 105 yaitu :

$\mathrm{P}($ Tidak Puas $\mid \mathrm{C})=\mathrm{P}(\mathrm{Rn} \mid \mathrm{C}) * \mathrm{P}($ Tidak Puas $)$

$=\mathrm{P}(101 \mid \mathrm{C}) * \mathrm{P}($ Tidak Puas $)$

$=0.0010 \times 0.220=0.0002$.

$\mathrm{P}($ Tidak Puas $\mid \mathrm{C})=\mathrm{P}(\mathrm{Rn} \mid \mathrm{C}) * \mathrm{P}($ Tidak Puas $)$

$=\mathrm{P}(102 \mid \mathrm{C}) * \mathrm{P}($ Tidak Puas $)$

$=0.0041 \times 0.220=0.0009$.

Dan begitu seterusnya sampai dengan data ke 105 . 
Setelah menghitung pemaksimalan dari nilai puas dan tidak puas, selanjutnya penulis membandingkan nilai puas dan tidak puas. Sehingga dapat diketahui mahasiswa tersebut termasuk kedalam kategori puas atau tidak puas.

$$
\begin{aligned}
\mathrm{R} 101 & =\text { puas }>=\text { tidak puas } \\
& =0,0491>=0,0002 \\
& =0.0491 \text { (puas). } \\
\mathrm{R} 102 & =\text { puas }>=\text { tidak puas } \\
& =0,1365>=0,0009 \\
& =0.1365 \text { (puas). } \\
\mathrm{R} 103 & =\text { puas }>=\text { tidak puas } \\
& =0,0551>=0,0002 \\
& =0.0551 \text { (puas). } \\
\mathrm{R} 104 & =\text { puas }>=\text { tidak puas } \\
& =0,0110>=0,0006 . \\
& =0.0110 \text { (puas). } \\
\mathrm{R} 105 & =\text { puas }>=\text { tidak puas } \\
& =0,0157>=0,0004 \\
& =0.0157 \text { (puas). }
\end{aligned}
$$

Sehingga dapat diketahui bahwa data testing dari data responden 101-105 memiliki klasifikasi puas.

\subsection{Implementasi Klasifikasi Naive Bayesian Pada Rapid Miner}

Berikut ini adalah pengolahan data dengan menggunakan naive bayesian pada Rapid Miner :

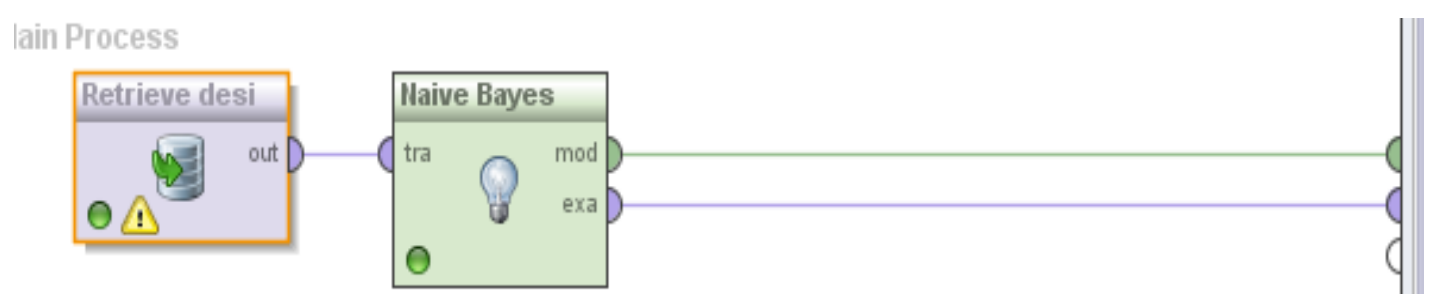

Gambar 1. Pemodelan Klasifikasi Naive Bayesian Pada Rapid Miner

Dengan menggunakn pemodelan klasifikasi naive bayesi seperti gambar di atas dengan mengklasifikasi 2 jenis klasifikasi yaitu puas dan tidak puas. Kemudian Berikut ini adalah hasil implementasi dari gambar diatas. 


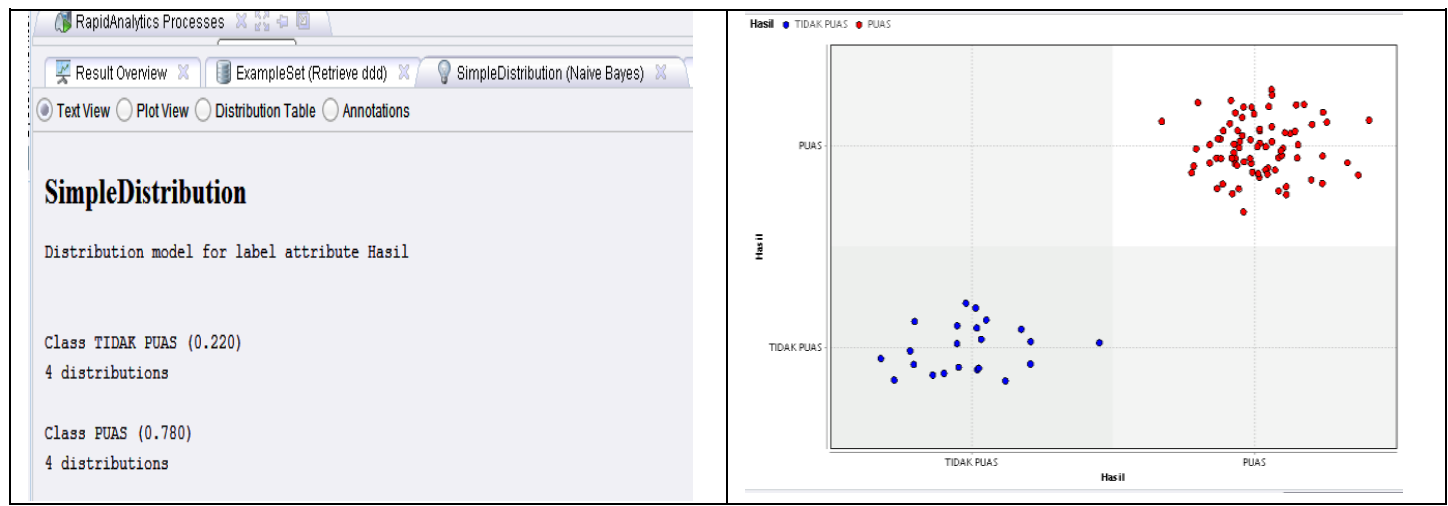

Gambar 2. Hasil Klasifikasi

\section{KESIMPULAN}

Berdasarkan hasil penelitian dan pembahasan yang telah dilakukan, dapat disimpulkan bahwa algoritma Naive Bayesian Classification (NBC) dapat digunakan sebagai salah satu metode untuk klasifikasi dalam menentukan kepuasan mahasiswa terhadap cara pengajaran dosen di STIKOM Tunas Bangsa Pematangsiantar dengan parameter yang digunakan dalam penelitian ini yaitu Komunikasi, Membangun Suasana Belajar, Penilaian Terhadap Mahasiswa dan Penyampaian Terhadap Materi. Berdasarkan 100 data training yang diolah di dalam Rapidminer, hasil pengujian menunjukkan akurasi sebesar $92.00 \%$ yaitu 22 responden menyatakan ketidakpuasan dan 78 responden menyatakan puas terhadap cara pengajaran dosen di STIKOM Tunas Bangsa Pematangsiantar. Dengan class precision pada prediksi tidak puas memiliki nilai $85.00 \%$, sedangkan pada prediksi puas memiliki nilai $93.75 \%$. Class recall pada true tidak puas memiliki nilai $72.27 \%$, sedangkan pada true puas memiliki nilai $96.16 \%$. Sehingga dapat dikatakan bahwa mahasiswa angkatan 2015 dan 2016 puas terhadap cara pengajaran dosen di STIKOM Tunas Bangsa Pematangsiantar. Untuk saran pada penelitian ini dapat di kembangkan dalam suatu aplikasi menggunakan bahasa pemrograman dan dapat di kembangkan dengan metode alghoritma klasifikasi yang lainnya.

\section{DAFTAR PUSTAKA}

[1] A. R. Razaq, "Interaksi pembelajaran efektif untuk berprestasi," Jurnal PILAR, vol. 2, 2014.

[2] A. Saleh, "Implementasi Metode Klasifikasi Naïve Bayes Dalam Memprediksi Besarnya Penggunaan Listrik Rumah Tangga," Citec Journal, vol. 2, no. 3, pp. 207-217, 2015.

[3] A. N. Putri, "PENERAPAN NAIVE BAYESIAN UNTUK PERANKINGAN KEGIATAN DI FAKULTAS TIK UNIVERSITAS SEMARANG," Jurnal SIMETRIS, vol. 8, no. 2, pp. 603-610, 2017.

[4] I. Parlina, A. P. Windarto, A. Wanto, and M. R. Lubis, "Memanfaatkan Algoritma K-Means dalam Menentukan Pegawai yang Layak Mengikuti Asessment Center untuk Clustering Program SDP," CESS (Journal of Computer Engineering System and Science), vol. 3, no. 1, pp. 87-93, 2018.

[5] S. Sudirman, A. P. Windarto, and A. Wanto, "Data Mining Tools | RapidMiner: K-Means Method on Clustering of Rice Crops by Province as Efforts to Stabilize Food Crops In Indonesia," IOP Conference Series: Materials Science and Engineering, vol. 420, no. 12089, pp. 1-8, 2018.

[6] R. W. Sari, A. Wanto, and A. P. Windarto, "Implementasi Rapidminer dengan Metode K-Means (Study Kasus: Imunisasi Campak pada Balita Berdasarkan Provinsi)," KOMIK (Konferensi 
Nasional Teknologi Informasi dan Komputer), vol. 2, no. 1, pp. 224-230, 2018.

[7] M. G. Sadewo, A. P. Windarto, and A. Wanto, "Penerapan Algoritma Clustering dalam Mengelompokkan Banyaknya Desa/Kelurahan Menurut Upaya Antisipasi/ Mitigasi Bencana Alam Menurut Provinsi dengan K-Means," KOMIK (Konferensi Nasional Teknologi Informasi dan Komputer), vol. 2, no. 1, pp. 311-319, 2018.

[8] C. Fadlan, S. Ningsih, and A. P. Windarto, "PENERAPAN METODE NAÏVE BAYES DALAM KLASIFIKASI KELAYAKAN KELUARGA PENERIMA BERAS RASTRA," JUTIM, vol. 3, no. 1, pp. $1-8,2018$.

[9] W. Muslehatin, M. Ibnu, and Mustakim, "Penerapan Naïve Bayes Classification untuk Klasifikasi Tingkat Kemungkinan Obesitas Mahasiswa Sistem Informasi UIN Suska Riau," Seminar Nasional Teknologi Informasi, Komunikasi dan Industri (SNTIKI), pp. 18-19, 2017.

[10] T. Sulastri, "Analisis Kepuasan Mahasiswa Terhadap Kinerja Dosen," JURNAL ILMIAH EKONOMI MANAJEMEN DAN KEWIRAUSAHAAN “OPTIMAL," vol. 10, no. 2, pp. 167-184, 2016.

[11] E. Elisa, "Analisa dan Penerapan Algoritma C4.5 Dalam Data Mining Untuk Mengidentifikasi Faktor-Faktor Penyebab Kecelakaan Kerja Kontruksi PT.Arupadhatu Adisesanti," Jurnal Online Informatika, vol. 2, no. 1, p. 36, 2017.

[12] Y. sulistio Nugroho, "Penerapan Algoritma C4.5 untuk Klasifikasi Predikat Kelulusan Mahasiswa Fakultas Komunikasi dan Informatika Universitas Muhammadiyah Surakarta," Prosiding Seminar Nasional Aplikasi Sains \& Teknologi (SNAST), no. November, pp. 1-6, 2014.

[13] H. M. M. AL Laroussi, "Implementasi algoritma naïve bayes sebagai proses seleksi penerima beasiswa libyan embassy berbasis web," 2015.

[14] Y. S. Nugroho, "DATA MINING MENGGUNAKAN ALGORITMA NAÏVE BAYES UNTUK KLASIFIKASI KELULUSAN MAHASISWA UNIVERSITAS," pp. 1-11, 2009. 